\title{
Discovering Belarusian History with Karatkievič
}

\author{
BY
}

\author{
PAULA BOROWSKA*
}

Uladzimir Karatkevich.

King Stakh's Wild Hunt, Glagoslav Publications: London, 2012. 291 pp.

$£ 18,80$ (paperback)

ISBN: 9781909156104.

King Stakh's Wild Hunt by Uladzimir Karatkievič came out with the Glagoslav Publications at the end of 2012. The book gives an opportunity to take a closer look at Belarusian history. The presented story inspired its adaptation into a film.

Uladzimir Karatkievič (1930-1984) is a prominent and influential Belarusian author, one of the main inspirations of the Belarusian national revival. He wrote prose, poetry, plays and screenplays but is particularly well-known for writing historical novels which deal with Belarusian history.

Uladzimir Karatkievič received a number of national literary awards, among them Jakub Kolas BSSR State Prize. His literary output laid the cornerstone for the genre of historical novel in Belarus.

Originally the book came out in 1964, when socialist Belarus was a part of the Soviet Union. It is interesting that Karatkievič places the story of the King Stakh's Wild Hunt at the end of the 19th century in the territory territory of today's Belarus. It constituted the far Western province of the Russian Empire and was under strong Polish cultural influence.

Andrej Bielarecki, the main character, as a researcher, is interested in folk legends. He in fact, however, attempts to understand the historical fate of the Belarusians. Karatkievič himself gives the impression that he speaks with the voice of the main character. The very story seems to be just an excuse for the author

Paula Borowska is an analyst of the Centre for Transition Studies in London. 
to research Belarusians. Bielarecki, with true care, asks 'Is my people really such a forgotten, such a dead nation?'.

Andrej Bielarecki is a young ethnographer. Getting lost in the course of a study trip, he finds shelter at the nearby castle in Marsh Firs. When he arrives there, he does not expect that staying at the gloomy castle will completely change his life. A girl, Nadzieja, the last descendant of the Janovski family, turns to be the owner of the castle.

The young mistress introduces Bielarecki to the old family legend of the King's Stakh Hunt for the members of the family. As the last living heir, convinced that she must inevitably become the victim of the Wild Hunt and thus, complete the curse. Nadzieja is of the interest to at least a few local gentlemen. Private animosities and greedy make them get involved in a mysteriously planned intrigue. Andrej decides to stay longer in Marsh Firs and solve the mysterious story. Their acquaintance gradually turns into a true friendship.

From the beginning, Andrej is sceptical of the legend of the Wild Hunt. With time, he finds more friends among the local peasantry ready to help him to solve the mysterious events. One if his confidants is Andrej Sviecilovič, a young scholar, who disagrees with the acts of social injustice transpiring in the community.

Karatkievič invites the reader into the world of the mysterious and engaging plot. The author depicts every particular detail of the landscape, which makes the story exceptionally picturesque and believable. The folk legend of the Wild Hunt, with some regional variations, was widespread throughout the European continent.

Out of his description looms a world of deep social injustice. Whereas the peasants carry the burden of hard work on the gentry's estates, spoiled local noble men are interested solely in enlarging their property and influence. Although the story of King Stakh's Wild Hunt is set in a certain historical and regional context, it depicts, however, a more universal reality of post-feudal 19th century Eastern Europe.

Apart from the romantic motif and the criminal story of intrigue, Karatkievič draws attention to the unjust relations between the gentry and peasants. The conflict he depicts in the book appears as a symbolic war between the groups of privileged local gentry and the subordinated peasants.

Karatkievič's main characters represent vibrant personalities. Albeit, as the action develops, the reader understands that a few characters are not who they are meant to be. With time the reader can, together with Andrej Bielarecki, find out the real nature of the local noblemen.

The main protagonist is a likeable person - well-educated, frank, deeply moral 
and noble person. He remains also sympathetic to his own nation: 'Unfortunate Belarus! A kind, complaisant, romantic people in the hands of rascals. And so it will always be while this nation allows itself to be made a fool of' (p.105). When he is hot on the trail in fuguring out the intrigue, he is in fact in pursuit of the lost Belarusian identity - its culture and language, while never losing sight of the social injustice experienced by the peasants. One might fall under the impression that it is the voice of Karatkievič himself, who together with his main protagonist, regrets the fate of the Belarusian nation.

Karatkievič/Bielarecki portrays his own nation - which posseses neither clear identity, nor respect for its cultural heritage or the Belarusian language, a nation torn between stronger Polish and Russian influences, between always as a borderland between other nations. He notes that 'Although Belarusian was spoken among the petty gentry at this time, the gentry of that stratum of society (...) did not know the language (...) language of the rest was a wondrous mixture of Russian, Polish and Belarusian' (p.84-85).

King Stakh's Wild Hunt is definitely worth reading, but for those who are not familiar at all with the Belarusian history and its cultural context, it may be a hard one to start with. Those who can read Belarusian should read the original to appreciate the full flavour of the richness of Karatkievič prose.

Uladzimir Karatkievič's output has a significant role as a 'guardian' of the collective memory of Belarusians today. As an author of historical novels he acted as both a researcher and archivist of Belarusians' history. Perhaps thus Karatkievič's King Stakh's Wild Hunt is book about the past and present. It proves his genius as an author and sensitivity as a commentator on the Belarusian nation. 